\title{
Analysis Of Temperature Effect on Struvite Scales Controlling in A Vertical Reactor
}

\author{
Sutiyono Sutiyono ${ }^{2 *}$, Luluk Edahwati ${ }^{2}$, Atika Nandini $^{1}$, WD Lestari ${ }^{2}$, Wiliandi Saputro ${ }^{2}$, Radissa Dzaky Issafira $^{2}$, \\ Ahmad Khairul Faizin ${ }^{2}$ \\ ${ }^{1}$ Chemical Engineering, Engineering, University of Pembangunan Nasional Veteran Jawa Timur, Indonesia \\ ${ }^{2}$ Mechanical Engineering, Engineering, University of Pembangunan Nasional Veteran Jawa Timur, Indonesia
}

\begin{abstract}
Scale is forming and controlling in industrial applications causes the clogs or decreasing in volume flows in the pipes, so increasing maintenance cost can occur as a consequence. Struvite discovered as Magnesium Ammonium Phosphate Hexahydrate $\left(\mathrm{MgNH}_{4} \mathrm{PO}_{4} \cdot 6 \mathrm{H}_{2} \mathrm{O}\right)$ and referred as a scale due to the heating process of fluid through pipes. The aim of this research was investigated the temperature effect on process of scales forming and controlling. The process was used a vertical bulkhead reactor. The process starts from mixing the equimolar solutions of $\mathrm{MgCl}_{2}, \mathrm{NH}_{4} \mathrm{OH}, \mathrm{H}_{3} \mathrm{PO} 4$ with 1: 1: 1 of ratio concentration. Then, crystallization process was carried out with the condition at the variation of temperature $\left(20-40^{\circ} \mathrm{C}\right)$, variation of $\mathrm{pH}$ value $(\mathrm{pH} 8-10)$ and variation of air inlet rate $(0.25 ; 0.50 ; 0.75 ; 1.0 ; 1.25 \mathrm{~L} / \mathrm{min})$ while the feed rate was $25 \mathrm{ml} / \mathrm{min}$. The process continues until the condition becomes steady state. The scale controlling process was determined by the presence of struvite deposits. The deposits were analyzed by using the XRF method to determine composition content. The optimal conditions were obtained at a temperature of $30^{\circ} \mathrm{C}, \mathrm{pH} 9$, and air rate of $1.25 \mathrm{~L} / \mathrm{min}$.
\end{abstract}

Keywords: Temperature Effect, Struvite, Vertical Reactor

\section{Introduction}

Heat exchanger, the most important heat exchange equipment, was needed in the industrial applications such as heat-power industry, chemical, food processing, refineries oil and gas and other industries[9]. A blockage in the process piping occurs due to struvite scales which reduce the diameter of pipes, thereby impairing the flow of fluids, water, oil, gas, etc. These scales impair the pipes causing higher operational production cost; increasing temperature in pipes, higher pressure, increasing time of drainage and higher pipe maintenance cost $[2,3]$. Scales are the deposition of organics and inorganics compound mainly formed at the inner surface of heat exchange equipment which is through the crystallization process of mineral compound in the water [4]. Chemically-defined, scales formed due to changes of ionic composition, $\mathrm{pH}$ level, pressure, and temperature. For an illustration, some molecules will affiliate to form a crystal nucleus in a supersaturated solution. The formed crystal has lower ionic charges and tends to agglomerate to form scales $[3,6]$. Mineral ions dissolving process in water was affected by pressure, temperature, contact time between water and formation medium. Water has a limited ability to keep these ionic compounds in solution. At specific pressure and temperature conditions, when the solubility value was exceeded, the compound will not further dissolve. However, the compound will separate from the solvent to form a solid [8].

Struvite or magnesium ammonium phosphate $\left(\mathrm{MgNH}_{4} \mathrm{PO}_{4} \cdot 6 \mathrm{H}_{2} \mathrm{O}\right)$ is a phospate mineral compound. The struvite formation process starts with mixing $\mathrm{Mg}^{2+}, \mathrm{NH}_{4}{ }^{+}$, $\mathrm{PO}_{4}{ }^{3-}$ ions in a solution. These reaction of ions in solution occur when the solubility product (Ksp) is lower than concentration of ions in solution.. Based on this [7], the reaction process to form struvite scales follows:

$$
\mathrm{Mg}^{2+}+\mathrm{NH}_{4}{ }^{+}+\mathrm{PO}_{4}{ }^{3-}+6 \mathrm{H}_{2} \mathrm{O} \rightarrow \mathrm{MgNH}_{4} \mathrm{PO}_{4} .6 \mathrm{H}_{2} \mathrm{O}
$$

Several factors that affect the controlling of sruvite scale $\left(\mathrm{MgNH}_{4} \mathrm{PO}_{4} \cdot 6 \mathrm{H}_{2} \mathrm{O}\right)$ process were $\mathrm{pH}$, saturation level and presence of ions in solution. Based on [10], the ratio concentration of 1:1:1 for $\mathrm{Mg}: \mathrm{N}: \mathrm{P}$ ions in the liquid phase was achieved of $86.4 \%$ to form struvite deposits. Similarly, with that, the aeration column crystallizer was used to investigate the removal of $\mathrm{PO}_{4}$ ions with ratio concentration of 1:1 (Mg:P) and obtained analysis result of $83.7 \%$ [1]. In an industrial application, struvite was found in pipelines as known as scales. The scales were indicated that contain magnesium ammonium phosphate compound. Industrial equipment that easily found scales were boilers or steam which are often flows with hot fluid.

This research was investigated to control the presence of struvite scales by using a vertical bulkhead reactor. The conditions of reactor were a volume of $498.75 \mathrm{~mL}$, the

\footnotetext{
*Corresponding author : sutiyono.tk@upnjatim.ac.id
} 
height of $50 \mathrm{~cm}$ with an outside diameter (OD) of $5 \mathrm{~cm}$ and inside diameter (ID) of $2.5 \mathrm{~cm}$. The reactor was equipped with bulkhead as an agitator. The mixing process was supported by the air that flowed into the reactor in counter-current flow with the incoming fluid flow. The function of these bulkheads was to break the air bubbles go into the reactor become smaller size bubbles, so that reaction between Magnesium Ammonium Phosphate Hexahydrate may occur in perfectly way. The results of struvite scales were analyzed by using the XRD method, which is analysis for the characterization of the material from the crystal. Meanwhile, the elemental composition of the crystals was analyzed by using the SEM method.

\section{Research and Methods}

With ratio concentration of 1: 1: 1 , mixing solutions $\left(\mathrm{MgCl}_{2}, \mathrm{NH}_{4} \mathrm{OH}, \mathrm{H}_{3} \mathrm{PO}_{4}\right)$ were prepared to control presence of struvite scales and the $\mathrm{NaOH}$ solution as a $\mathrm{pH}$ controller. The instrument of vertical reactors can be seen in figure 1 below :

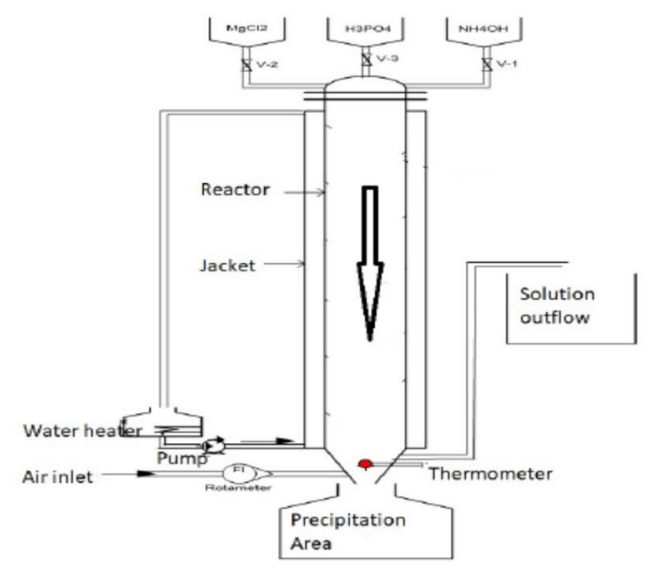

Fig.1. Schematic Diagram of Vertical Bulkhead Reactor

The mixing solution was transferred to the reactor approximately $3 / 4$ of reactor's height. The air flow was fed into the reactor, as a counter-current flow, with variation of inlet air rate of $0.25 \mathrm{~L} / \mathrm{min} ; 0.50 \mathrm{~L} / \mathrm{min} ; 0.75 \mathrm{~L} / \mathrm{min} ; 1.0$ $\mathrm{L} / \mathrm{min} ; 1.25 \mathrm{~L} / \mathrm{min}$. A NaOH solution was added gradually to reach the variation of $\mathrm{pH}$ value conditions $(\mathrm{pH} 8 ; 9 ; 10)$. The operation condition was maintained at variation temperature of $20^{\circ} \mathrm{C} ; 30^{\circ} \mathrm{C} ; 40^{\circ} \mathrm{C}$. The process was continued until the condition become steady state. The $X R F$ (X-ray Fluorescence) method was used to analyze the composition of struvite deposits.

\section{Result and Discussion}

XRF (X-ray Fluorescence) method was an element analysis method that forms material by interaction between X-Ray and compound. These 3 tables (Table 13) show the analysis result of struvite for different $\mathrm{pH}$ values $(\mathrm{pH} 8 ; 9 ; 10)$.
Table 1. Analysis Result of XRF method at $\mathrm{pH}$ value of 8

\begin{tabular}{ccccccc}
\hline \multirow{2}{*}{ Temperature } & \multirow{2}{*}{$\begin{array}{c}\text { Component } \\
(\%)\end{array}$} & \multicolumn{5}{c}{ Air Rate (L/min) } \\
\cline { 3 - 7 } & $\mathrm{Mg}$ & 0.25 & 0.5 & 0.75 & 1.0 & 1.25 \\
\hline \multirow{2}{*}{$20^{\circ} \mathrm{C}$} & $\mathrm{P}$ & 22.4 & 31.5 & 32.7 & 36.4 & 37.4 \\
& $\mathrm{P}$ & 23.6 & 26.8 & 27.6 & 28.5 \\
$30{ }^{\circ} \mathrm{C}$ & $\mathrm{Mg}$ & 33.5 & 30.2 & 32.3 & 34.4 & 38.9 \\
& $\mathrm{P}$ & 28.4 & 29.2 & 29.8 & 29.9 & 30.3 \\
$40{ }^{\circ} \mathrm{C}$ & $\mathrm{Mg}$ & 32.2 & 30.2 & 31.4 & 32.4 & 33.9 \\
& $\mathrm{P}$ & 27.8 & 28.2 & 28.8 & 29.4 & 29.7 \\
\hline
\end{tabular}

Table 1, shows analysis result of mineral component at $\mathrm{pH}$ value of 8 with different temperature. The magnesium $(\mathrm{Mg})$ content of $38.9 \%$ and phosphor $(\mathrm{P})$ content of $30.3 \%$ was obtained at $30^{\circ} \mathrm{C}$ with air rate of $1.25 \mathrm{~L} / \mathrm{min}$.

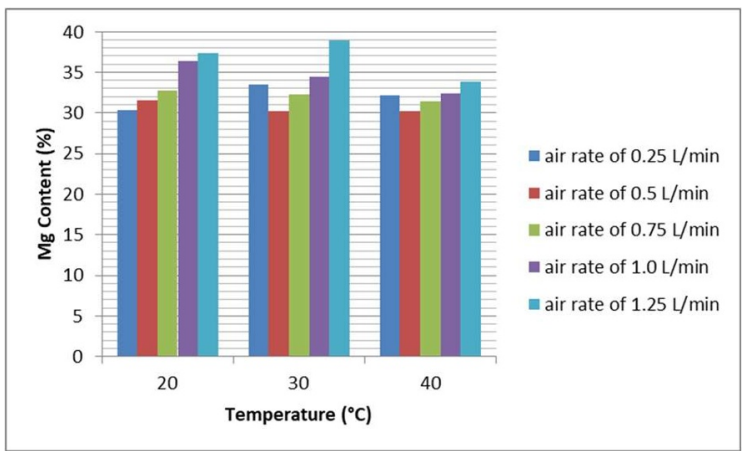

Fig.2. Effect variation of temperature on percentage of $\mathrm{Mg}$ content (\%) at $\mathrm{pH} 8$

Figure 2, shows the correlation between temperature with the percentage of $\mathrm{Mg}$ content on struvite mineral. The high $\mathrm{Mg}$ content was obtained by using air rate of $1.25 \mathrm{~L} / \mathrm{min}$ in different temperature. Similarly with Figure 2., on Figure 3. shows the correlation between temperature with the percentage of $\mathrm{P}$ content on struvite mineral. The high $\mathrm{P}$ content was obtained by using air rate of $1.25 \mathrm{~L} / \mathrm{min}$ in different temperature. Depend on ${ }^{[11]}$, air rate affects the formation and controlling process of struvite by using this bulkhead reactor. The purpose of the air rate was to increase the speed of mixing so reaction can occurs and lead to homogeneity solution. The higher of air rate, it will reaches a homogeneous condition perfectly. The highest percentage of $\mathrm{Mg}$ and $\mathrm{P}$ content was achieved at temperature of $30^{\circ} \mathrm{C}$. 


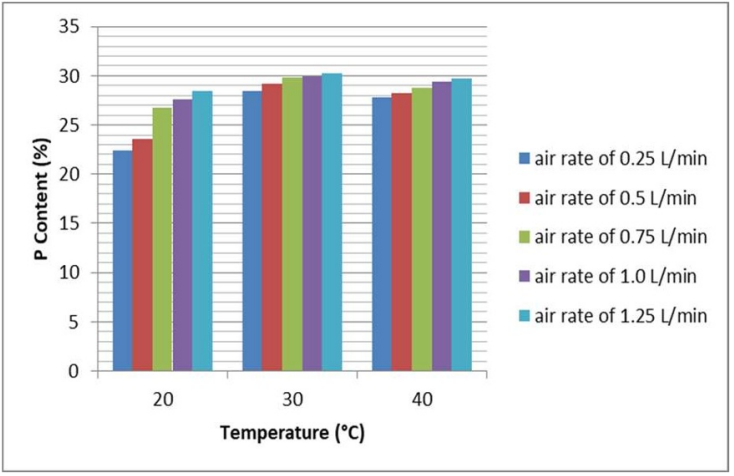

Fig. 3. Effect variation of temperature on percentage of $\mathrm{P}$ at $\mathrm{pH} 8$

Table 2. Analysis Result of XRF method at $\mathrm{pH}$ value of 9

\begin{tabular}{lcccccc}
\hline & & \multicolumn{5}{c}{ Air Rate (L/mins) } \\
\cline { 3 - 7 } Temp. & $\begin{array}{c}\text { Component } \\
\text { (\%) }\end{array}$ & 0.25 & 0.5 & 0.75 & 1.0 & 1.25 \\
\hline \multirow{2}{*}{$20^{\circ} \mathrm{C}$} & $\mathrm{Mg}$ & 36.5 & 36.8 & 38.4 & 39.6 & 40.2 \\
& $\mathrm{P}$ & 37.4 & 38.2 & 38.8 & 38.9 & 39.3 \\
$30{ }^{\circ} \mathrm{C}$ & $\mathrm{Mg}$ & 40.5 & 40.2 & 41.4 & 42.4 & 43.9 \\
& $\mathrm{P}$ & 38.4 & 39.2 & 39.8 & 40.04 & 40.3 \\
$40^{\circ} \mathrm{C}$ & $\mathrm{Mg}$ & 35.5 & 36.2 & 41.4 & 42.4 & 41.9 \\
& $\mathrm{P}$ & 35.4 & 35.9 & 36.8 & 37.4 & 38.3 \\
\hline
\end{tabular}

Table 2, shows analysis result of mineral component at $\mathrm{pH}$ value of 9. Magnesium content of $43.9 \%$ and Phospor content of $40.3 \%$ were obtained with the operational condition at $30^{\circ} \mathrm{C}, \mathrm{pH} 9$ and air rate of 1.25 $\mathrm{L} / \mathrm{mins}$.

Table 3. Analysis Result of XRF methodat $\mathrm{pH}$ value of 10

\begin{tabular}{ccccccc}
\hline \multirow{2}{*}{ Temp. } & $\begin{array}{c}\text { Component } \\
(\%)\end{array}$ & \multicolumn{5}{c}{ Air Rate (L/mins) } \\
\cline { 3 - 7 } & & 0.25 & 0.5 & 0.75 & 1.0 & 1.25 \\
\hline \multirow{2}{*}{$20^{\circ} \mathrm{C}$} & $\mathrm{Mg}$ & 28.5 & 28.8 & 29.07 & 29.4 & 30.9 \\
& $\mathrm{P}$ & 30.4 & 31.02 & 31.8 & 32.4 & 33.1 \\
$30^{\circ} \mathrm{C}$ & $\mathrm{Mg}$ & 30.5 & 30.2 & 32.4 & 32.4 & 33.9 \\
& $\mathrm{P}$ & 32.4 & 33.02 & 33.3 & 34.4 & 35.3 \\
$40^{\circ} \mathrm{C}$ & $\mathrm{Mg}$ & 28.5 & 29.02 & 29.4 & 30.04 & 31.07 \\
& $\mathrm{P}$ & 31.4 & 31.7 & 31.8 & 32.4 & 32.51 \\
\hline
\end{tabular}

Table 3, shows analysis result of mineral component at $\mathrm{pH}$ value of 10 . Magnesium content of $33.9 \%$ and Phospor content of $35.3 \%$ were obtained with the operational condition at $30^{\circ} \mathrm{C}, \mathrm{pH} 10$ and air rate of 1.25 L/mins.

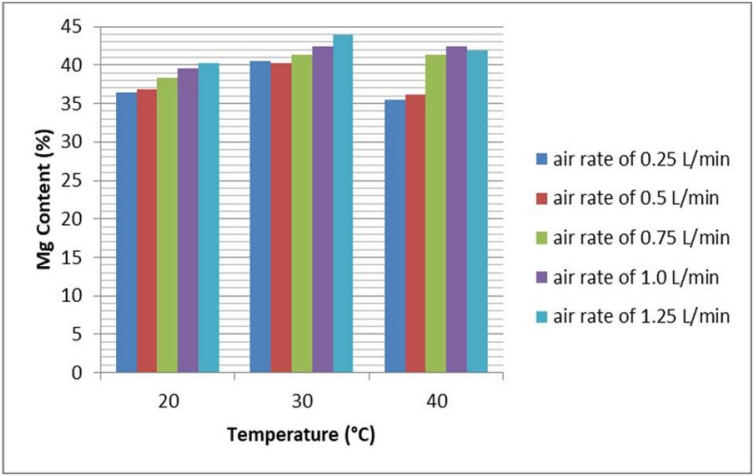

Fig. 4. Effect variation of temperature on percentage of $\mathrm{Mg}$ at $\mathrm{pH} 9$

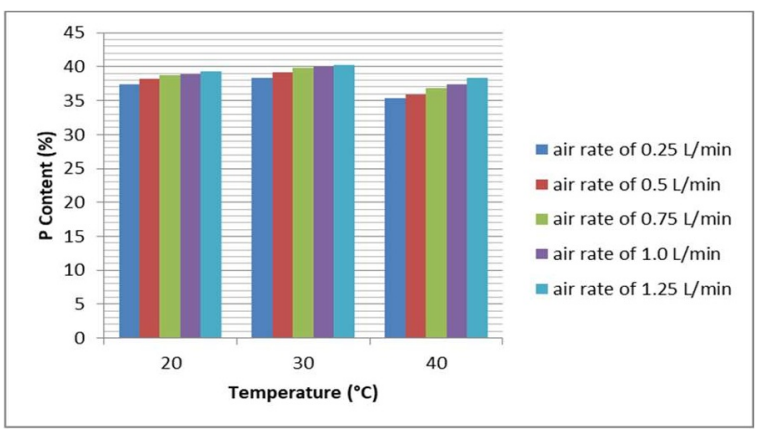

Fig.5. Effect variation of temperature on percentage of $\mathrm{P}$ at $\mathrm{pH} 9$

The correlation between effect of temperature with air rate on struvite compound showed at Figure 4. and Figure 5. In Figure 4. the high component of $\mathrm{Mg}$ was obtained at temperature of $30^{\circ} \mathrm{C}$ with different air rate on $0.25 ; 0.5$; $0.75 ; 1.0 ; 1.25 \mathrm{~L} / \mathrm{min} .{ }^{[5]}$ shows that struvite solubility increase with the increasing of temperature until $35^{\circ} \mathrm{C}$ and then decreasing. The solubility product (Ksp) will increase from $0.436 \times 10^{-4}$ to $5.920 \times 10^{-14}$ at increasing of temperature $10{ }^{\circ} \mathrm{C}$ to $35^{\circ} \mathrm{C}$. Depends on it, show that temperature has effect on the process of formation struvite. When the temperature solution of $35{ }^{\circ} \mathrm{C}$ then decreased to $10^{\circ} \mathrm{C}$, struvite crystal will easily form in solution. In Figure 5. shows that the percentage of phosphor content decrease at temperature of $40{ }^{\circ} \mathrm{C}$

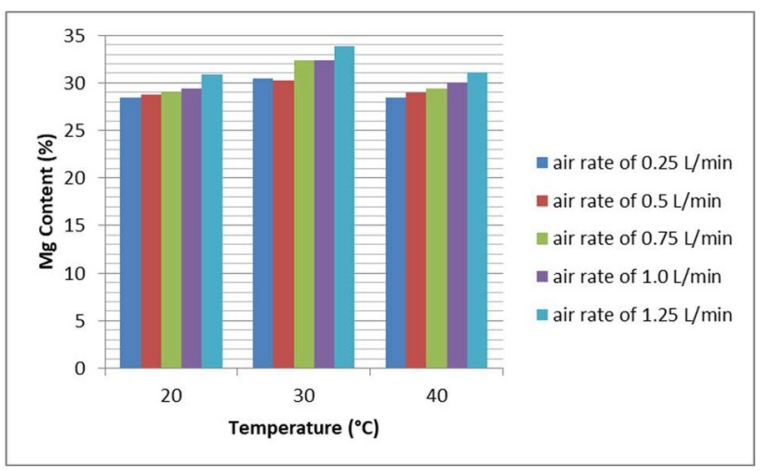

Fig. 6. Effect variation of temperature on percentage of $\mathrm{Mg}$ at $\mathrm{pH} 10$ 


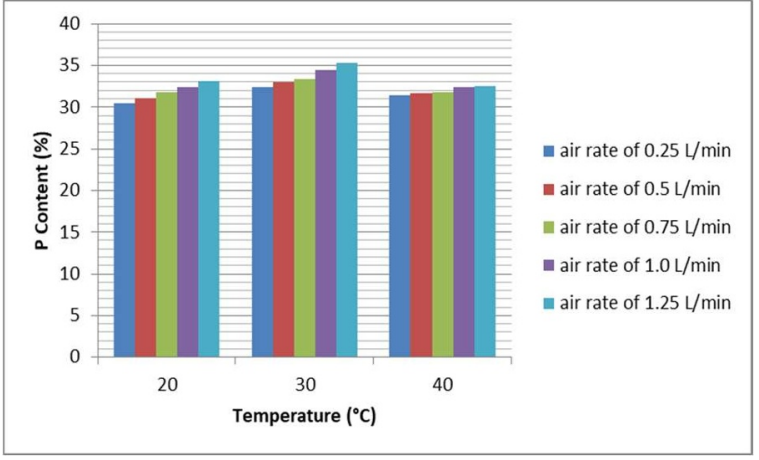

Fig.7. Effect variation of temperature on percentage of $\mathrm{P}$ at $\mathrm{pH} 10$

Figure 6 and Figure 7, shows the correlation between temperature with the percentage of $\mathrm{Mg}$ content on struvite mineral at different air rate. The high $\mathrm{Mg}$ content was obtained by using air rate of $1.25 \mathrm{~L} / \mathrm{min}$. Similarly with high $\mathrm{Mg}$ content, the high $\mathrm{P}$ content also obtains at air rate $1.25 \mathrm{~L} / \mathrm{min}$.

At variation of temperature, optimal temperature to control the struvite scale was obtained at $30^{\circ} \mathrm{C}$. The $\mathrm{pH}$ value of 9 was obtained as optimal condition. The effect of $\mathrm{pH}$ value was one of the most important factors for the process to form the struvite deposits. When $\mathrm{pH}$ value was higher, more struvite deposits were forming. The optimal condition for this research was obtained at temperature of $30^{\circ} \mathrm{C}, \mathrm{pH}$ value of 9 , air rate of $1.25 \mathrm{~L} / \mathrm{min}$, analysis result for magnesium content of $43.9 \%$ and phosphor content of $40.3 \%$.

\section{Conclusion}

The temperature, $\mathrm{pH}$, air rate were very important factors that effect to control struvite scales on a bulkhead vertical reactor. The condition at $30{ }^{\circ} \mathrm{C}, \mathrm{pH} \mathrm{9}$, air rate of 1.25 $\mathrm{L} / \mathrm{min}$ were determined as a optimal condition. On this optimal condition, the highest magnesium content of $43.9 \%$ and phosphor content of $40.3 \%$ was obtained as an analysis result.

\section{References}

1. E. Ariyanto, A. Melani, T. Anggraini, Penyisihan PO4 dalam air limbah rumah sakit untuk produksi pupuk struvite, in Seminar Nasional Sains dan Teknologi, 17 November 2015, Jakarta-Indonesia (2015)

2. Asnawati, Pengaruh temperatur terhadap reaksi fosfonat dalam inhibitor kerak pada sumur minyak, Jurnal Ilmu Dasar, (2): 20-26 (2001)

3. Z. Belarbi, J. Gamby, L. Makhloufi, B. Tribollet, Nucleation-growth process of calcium carbonate on rotating disk electrode in mineral potable water, Electrochimica Acta 109, p. 623-629 (2013)

4. A. Bhatia, Cooling Water Problems and Solutions, Continuing Education and Development, Inc. 9 Greyridge Farm Court Stony Point, New York. (2003)
5. M. I. H. Bhuiyan, D.S. Mavinic, R.D. Beckie, Nucleation and growth kinetics of struvite in a fluidized bed reactor, Journal of Crystal Growth $\mathbf{3 1 0}$, p. 1187-1194 (2008)

6. D.E. Lestari, Kimia Air, Pelatihan Operator dan Supervisor Reaktor Riset, Pusat Pendidikan dan Pelatihan BATAN. Serpong. (2008)

7. X. Liu, G. Wen, Z. Hu, J. Wang, Coupling effects of $\mathrm{pH}$ and $\mathrm{Mg} / \mathrm{P}$ ratio on $\mathrm{P}$ recovery from anaerobic digester supernatant by struvite formation, Journal of Cleaner Production, (to be published)

8. R.P. Sari, Studi Penanggulangan Problem Scale dari Near- Wellbore Hingga Flowline di Lapangan Minyak Limau, FT UI, Depok (2011)

9. V. A. Prisyazhniuk, Physico-chemical principles of preventing salts crystallization on heat-exchange surfaces, Applied Thermal Engineering, 29 (14-15), pp: 3182-3188, (2009)

10. Y.D. Yilmazel, G.N. Demirer, Removal and recovery of nutrients as struvite from anaerobic digestion residues of poultry manure, Environmental Technology, 32:7, p. 783-794 (2011)

11. S. Sutiyono, L. Edahwati, D.S. Perwitasari, S. Muryanto, J. Jamari, A. P. Bayuseno, Synthesis and characterization of struvite family crystals by an aqueous precipitation method, in MATEC Web of Conferences. 15-17 October 2015, Bali (2016) 